\title{
PERFORMANCE APPRAISAL SYSTEM IN RESEARCH AND DEVELOPMENTAL (R \& D) LIBRARIES OF KARNATAKA STATE: A STUDY
}

\author{
Dr. Rajashekara.G.R \\ Librarian-Senior Scale \\ Government First Grade College, Bhadravathi-577301, Shivamogga, India \\ drrajashekargr@gmail.com
}

\section{Manuscript Info Abstract}

\section{Manuscript History}

Received: 10 February 2021

Final Accepted: 22 March 2021

Published: 10 April 2021

Online Published: May 2021

DOI: http:/ /dx.doi.org/10.35337/EIJLITR.2021.1505

(C) Dr. Rajashekara .G .R The Author. This is an open access article under the terms of the Creative Commons Attribution License 4.0, which allows use, distribution and reproduction in any medium, provided the original work is properly cited.

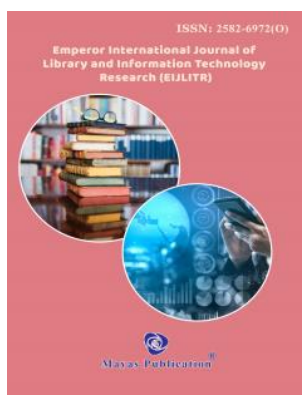

Creative work library maintains savvy or consistent assessment and will generally consolidate fundamental similarly as discretionary sources; it for the most part plate to recuperate all new information related to affiliation research work and attempt to offer permission to basic information resources in different constructions. Execution assessment also impacts other human resource rehearses like enlistment and assurance, getting ready and headway, pay, and specialist relations. It is normal that better execution assessment can strongly influence specialist work satisfaction. Hence, specialists should be set up to work new systems and supplies, to manage the present similarly as new positions even more effectively. It targets improving the affiliation's display through the redesigned execution of its laborers. Considering above real factors an assessment has been coordinated to be acclimate with the show assessment system proceeded in $\mathrm{R}$ and $\mathrm{D}$ libraries

Keywords:: Research Library, R and D Library, Performance Appraisal, Special Library

\section{INTRODUCTION}

The job of exploration and formative ( $R$ and $D)$ administrator in the dramatically developing computerized climate has gotten very testing. The current ability and information on research library proficient don't serve the changing data needs and development of library administrations. Lately library experts are compelled to receive all cutting edge devices of ICT dependent on their client's assumption and future requirements. So it makes expanded pressing factor throughout the long term. This expanding pressing factor can be controlled from giving satisfactory preparing to library experts at normal stretches. Execution examination is one of the most established and most widespread techniques for human asset 
the executives. Execution examination is a deliberate interaction to assess the exhibition of a worker for explicit period through standard strategies like positioning, reviewing, correlation technique and so forth The principle destinations of worker's presentation examination are to persuade the representative to upgrade the exhibition, keep a stock and quality in workers, put forward targets and objectives according to execution norms, assess worker execution, distinguish preparing and improvement needs and award execution. Execution evaluation additionally impacts other human asset practices like enlistment and choice, preparing and advancement, pay, and worker relations. It is accepted that better execution evaluation can emphatically affect representative occupation fulfillment. Considering above realities an examination has been directed to familiarize with the exhibition evaluation framework continued in $\mathrm{R}$ and D libraries.

\section{OBJECTIVES OF THE STUDY}

$>$ To know the segment status of $\mathrm{R}$ and $\mathrm{D}$ libraries of Karnataka state.

$>$ To recognize the $\mathrm{R}$ and $\mathrm{D}$ library expert's fulfillment on execution examination framework in association.

$>$ To know the presentation evaluation guidelines continued in $\mathrm{R}$ and $\mathrm{D}$ libraries.

$>$ To make out the male and female experts proportion in Indian R and D libraries.

$>$ To discover the social foundation and conjugal status of $\mathrm{R}$ and $\mathrm{D}$ libraries.

$>$ To decide the presentation evaluation recurrence in $\mathrm{R}$ and $\mathrm{D}$ libraries.

$>$ To realize the reaction on evaluating one-sided Performance Appraisal Content

\section{Need of the Study}

The need of this examination is to evaluate the presentation framework in Research and Developmental $(\mathrm{R}$ and $\mathrm{D})$ libraries in Karnataka State, India with a perspective on distinguish nature of execution examination framework, fulfillment of representatives and survey of it.

\section{Scope and Limitation of the Study}

The current examination is intended to investigation of execution evaluation framework in Research and Developmental libraries of Karnataka state, INDIA as it were.

\section{METHODOLOGY}

To accomplish the goals of the examination study exploration and poll strategy was utilized for this investigation. Information is gathered predominantly from essential source and irregular testing technique was embraced to gather the information. An organized close finished poll was intended for the investigation and it was circulated $200 \mathrm{R}$ and D libraries experts working in $45 \mathrm{R}$ and D libraries of Karnataka State.

\section{Data Analysis and Interpretation}

The analyst endeavored to guarantee an example that would address the populace and consequently chose basic irregular strategy for the investigation. The polls were appropriated to the experts and were given sufficient opportunity to go through it and react to the inquiries in that. The information gathered were arranged and investigated measurably utilizing proper elucidating procedures remembered for Software Package for Social Sciences (SPSS) V.20.

TABLE-1

DISTRIBUTION OF QUESTIONNAIRE AND RESPONSE RECEIVED

\begin{tabular}{|l|c|c||c||}
\hline \multirow{2}{*}{ Nature of Library } & \multicolumn{2}{|c|}{ Number of Questionnaires } & \multirow{2}{*}{$\begin{array}{c}\text { Percentage of } \\
\text { Response }\end{array}$} \\
\cline { 2 - 3 } & Distributed & Received & $87.5 \%$ \\
\hline \hline R \& D Library & 216 & 189 & \\
\hline
\end{tabular}

Table-6.1 verbalizes that among absolute of $250 \mathrm{R}$ and D library experts, 216 surveys were circulated and figured out how to gather 189 filled polls back with generally speaking reaction pace of $87.5 \%$. 
TABLE-2

DISTRIBUTION OF PROFESSIONALS BY GENDER

\begin{tabular}{|c||c|c|c||}
\hline \multirow{2}{*}{ Nature of Library } & \multicolumn{2}{|c|}{ Gender } & \multirow{2}{*}{ Total } \\
\cline { 2 - 3 } & Male & Female & \multirow{2}{*}{$189(100 \%)$} \\
\hline \hline R \& D Library & $102(54 \%)$ & $87(46 \%)$ & 180 \\
\hline
\end{tabular}

It is seen from the table- 6.2 that, greater part of $102(54 \%)$ of experts, has a place with male class and 87 $(46 \%)$ of experts are females classification in $\mathrm{R}$ and $\mathrm{D}$ libraries.

TABLE -3

DISTRIBUTION OF PROFESSIONALS BY AGE

\begin{tabular}{|c|c|c|c|c|c|}
\hline \multirow[b]{2}{*}{ Nature of Library } & \multicolumn{4}{|c|}{ Age (in Years) } & \multirow[b]{2}{*}{ Total } \\
\hline & $\begin{array}{l}\text { Less than } \\
30 \text { Years }\end{array}$ & $\begin{array}{l}31-40 \\
\text { Years }\end{array}$ & $\begin{array}{l}41-50 \\
\text { Years }\end{array}$ & $\begin{array}{c}51 \text { \& Above } \\
\text { Years }\end{array}$ & \\
\hline R \& D Library & $17(9 \%)$ & $74(39.2 \%)$ & $40(21.2 \%)$ & $58(30.7 \%)$ & $189(100 \%)$ \\
\hline
\end{tabular}

Information in table-6.3 delineates the diverse age gathering of $\mathrm{R}$ and $\mathrm{D}$ library experts utilized in Karnataka State (INDIA). Above examination tracked down that most noteworthy number $74(39.2 \%)$ of experts are in the age gathering of 31-40 years, trailed by $58(30.7 \%)$ experts are 51 or more years, 40 (21.2\%) of experts are 41-50 years age bunch and staying $17(9 \%)$ of experts are in under 30 years old gathering separately.

TABLE-4

DISTRIBUTION OF PROFESSIONALS BY MARITAL STATUS

\begin{tabular}{|c|c|c|c|}
\hline \multirow{2}{*}{ Nature of Library } & \multicolumn{2}{|c|}{ Marital Status } & \multirow{2}{*}{ Total } \\
\hline & Married & Unmarried & \\
\hline R \& D Library & $158(83.6 \%)$ & $31(16.4 \%)$ & $189(100 \%)$ \\
\hline
\end{tabular}

Above table-6.4 shows that, most extreme number 158 (83.6\%) of experts are hitched and $31(16.4 \%)$ are un-hitched in $\mathrm{R}$ and $\mathrm{D}$ libraries.

TABLE-5

DISTRIBUTION OF PROFESSIONALS BY SOCIAL BACKGROUND

\begin{tabular}{||c|c|c|c||c||}
\hline \multirow{2}{*}{ Nature of Library } & \multicolumn{3}{|c||}{ Social Background } & \multirow{2}{*}{ Total } \\
\cline { 2 - 4 } & Urban & Semi-urban & Rural & \multirow{2}{*}{$189(100 \%)$} \\
\hline \hline R \& D Library & $88(46.6 \%)$ & $55(29.1 \%)$ & $46(24.3 \%)$ & 189 \\
\hline
\end{tabular}

It is recognizes from table-6.5 that, huge number 88 (46.6\%) of experts are has a place with metropolitan class went before by $55(29.1 \%)$ are semi-metropolitan and $46(24.3 \%)$ of experts are from rustic foundation. 
TABLE-6

EXISTENCE OF STANDARD PERFORMANCE APPRAISAL SYSTEM

\begin{tabular}{|l||c|c||c||}
\hline \multirow{2}{*}{ Nature of Library } & \multicolumn{2}{|c|}{ Existence of Standard PA System } & \multirow{2}{*}{ Total } \\
\cline { 2 - 3 } & Yes & No & \\
\hline \hline R \&D Library & $171(90.5 \%)$ & $18(9.5 \%)$ & $189(100 \%)$ \\
\hline
\end{tabular}

Information in the table-6.6 edifies the response of respondents on presence of standard execution examination framework in $\mathrm{R}$ and $\mathrm{D}$ association. It is perceived from the above table that greatest rate $(90.5 \%)$ of respondents believed their associations have standard execution evaluation framework. From the above examination in a word it very well may be set up that, there is a need to carry out standard execution evaluation framework in $\mathrm{R}$ and $\mathrm{D}$ association.

TABLE-7

SATISFACTION ON PERFORMANCE APPRAISAL (PA) STANDARDS

\begin{tabular}{|c|c|c|c|c|}
\hline \multirow{2}{*}{$\begin{array}{l}\text { Nature of } \\
\text { Library }\end{array}$} & \multicolumn{3}{|c|}{ Satisfaction on Performance Appraisal Standards } & \multirow{2}{*}{ Total } \\
\hline & Yes & No & NA & \\
\hline R \&D Library & $128(67.7 \%)$ & $43(22.75 \%)$ & $18(9.5 \%)$ & $189(100 \%)$ \\
\hline
\end{tabular}

Table-6.7, it portrays that, out of complete 189 respondent's larger part $128(67.7 \%)$ of respondents communicated their fulfillment and $43(22.75 \%)$ of respondents communicated their disappointment. Based on above investigation, it very well might be inferred that, out of absolute respondents right around $33 \%$ of respondents have communicated their fulfillment about existing execution evaluation framework. Fulfillment of respondents on execution evaluation in association of the investigation is like the examination directed by Gowda (2009). In this examination, it is discovered that respondents were happy with execution assessment. Additionally, Baro, Fyneman and Zukemefa (2013) concentrate likewise uncovered that catalogers of college libraries in Nigeria were happy with execution assessment framework.

TABLE-8

COMMUNICATION OF PERFORMANCE APPRAISAL (PA) CONTENT

\begin{tabular}{|c||c|c|c||c||}
\hline \multirow{2}{*}{ Nature of Library } & \multicolumn{2}{|c||}{ Communication of PA Content } & \multirow{2}{*}{ Total } \\
\cline { 2 - 4 } & Yes & No & NA & \\
\hline \hline R \&D Library & $149(78.8 \%)$ & $22(11.6 \%)$ & $18(9.5 \%)$ & $189(100 \%)$ \\
\hline
\end{tabular}

Based on correspondence of execution examination report substance to respondents in exceptional libraries, it tends to be enunciated from the table- 6.8 that, out of absolute 189 respondents' $78.8 \%$ of respondent's believed execution evaluation content is conveyed and $11.6 \%$ thought not imparted. Shockingly $9.5 \%$ of the respondents communicated examination report content isn't imparted to them. From above examination it very well may be interpreted that, there is a need to upkeep of straightforwardness in execution evaluation framework in association.

Table-9

Organization Response on Reviewing Biased Performance Appraisal Content

\begin{tabular}{|c|c|c|c|c|}
\hline \multirow{2}{*}{ Nature of Library } & \multicolumn{3}{|c|}{ Reviewing Biased Performance Appraisal Content } & \multirow{2}{*}{ Total } \\
\hline & Yes & No & NA & \\
\hline R \&D Library & $49(25.92 \%)$ & $122(64.6 \%)$ & $18(9.5 \%)$ & $189(100 \%)$ \\
\hline
\end{tabular}

Taking in to thought of association reaction on representative's disappointment about evaluating onesided execution examination content, it tends to be seen from the table-6.9 that greater part $122(64.6 \%)$ of respondents passed on their disappointment and 49 (25.92\%) of respondents passed on fulfillment 
TABLE-10

FREQUENCY OF PERFORMANCE APPRAISAL (PA)

\begin{tabular}{||c||c|c|c||c||c||}
\hline \multirow{2}{*}{ Nature of Library } & \multicolumn{3}{|c|}{ Frequency of Performance Appraisal (PA) } & \multirow{2}{*}{ Total } \\
\cline { 2 - 4 } & Quarterly & Half Yearly & Annually & Others & \multirow{2}{*}{$189(100 \%)$} \\
\hline \multirow{2}{*}{ R \&D Library } & $\begin{array}{c}8 \\
(4.2 \%)\end{array}$ & $\begin{array}{c}1 \\
(0.5 \%)\end{array}$ & $\begin{array}{c}162 \\
(85.7 \%)\end{array}$ & $18(9.5 \%)$ & \multirow{2}{*}{189} \\
\hline
\end{tabular}

Table-6.10 depicts the assessment of respondents on recurrence of the exhibition evaluation. It very well may be featured from the above table that, $85.7 \%$ of respondent's presentation is assessed yearly.

\section{CONCLUSION}

In the time of computerized climate, the $\mathrm{R}$ and $\mathrm{D}$ library experts likewise understand the need to create and give forward-thinking data administration to meet the necessities of the clients. Preparing and improvement software engineers are key issues of profession advancement of each representative in an establishment. To work with quality administrations to the library clients particularly in this data blast and IT climate custodians and library staffs need to invest in constant learning and besides preparing and advancement exercises. Subsequently, concerned R and D library specialists ought to appropriately react to representative's misery on execution examination framework or individual evaluation report. To determine this issue there ought to be legitimate conversation with workers prior to outlining execution evaluation principles and made the examination framework more straightforward.

\section{REFERENCE}

1. Baro, E., Fyneman, E., \& Zoukemefa (2013). Job satisfaction among cataloguer librarians in university libraries in Nigeria. Cataloging \& Classification Quarterly, 51(6), 675-696.

2. Chand, Salek and Dheer, Lalita (2009). Training: A Technique for Empowerment of Library professionals Talent Development and Strategies, ICAL, p. 356-360.

3. Chhabra, T.N. Human Resource Management-Concepts and Issues, $4^{\text {th }}$ edition, Shamp Co. Delhi.

4. Gouse Riajuddin, Md. (2008) Newspaper Libraries in Andhra Pradesh(India) : A study on Emergence, Services and professional Attitude to words Automation, pp.95-97.

5. Gowda, P.M. (2009). Satisfaction levels related to management issues among LIS professionals. Annals of Library and Information Studies, 56, 227-235.

6. Khan, Amjid and Ahmed, Shamshad (2013). Job Satisfaction among Librarians in the Universities of Khyber Pakhtunkhwa, Pakistan: A Survey. Library Philosophy and Practice, 906. http://digitalcommons.unl.edu/libphilprac/9061 (Accessed on 15-9-2015)

7. Natrajan, M. (2008). Training needs for Library professionals: Current \& future pattern. International Conference .NEHU, Shillong.

8. Olaniyan D. A \& Ojo, L. (2008). Staff training and development: A vital tool for organizational effectiveness. Euro Journals 24(3):326-331.

9. Pan, J. \& Hovde, K. (2010). Professional Development for Academic Librarians: Needs, Resources, and Administrative Support. Chinese Librarianship: an International Electronic Journal, 29. URL: http://www.iclc.us/cliej/cl29PH.htm26

10. Paul, N.K. (2002). Manpower training in University Libraries with special reference to NorthEastern Hill University Library and Assam University Library: A study, Un-published dissertation report, Gauhati University, pp. 6.

11. Paul, N.K. (2014). A Study of the effects of Manpower training and job satisfaction of the library professionals in North East India, Assam University, PhD thesis. Pp.165-204

12. Spector, P. E. (1997). Job satisfaction application assessment: Causes and consequences, Thousand oaks', Calif, Sage Publications.

13. Rowden, R.W. \& Conine Jr.C-T (2003), The Relationship between workplace learning and job satisfaction in U.S. Small Commercial Bank. In S.A. Lynna \& T.M. Egan (Eds.) AHRD, Conference Proceedings (pp. 459-466).

14. Violino, B. (2001). Still the Money Network Computing, 12 (16), 66.

15. http;/shodhganga.inflibnet.ac.in/bitstream/10603/205/10/10 